\title{
Localised pneumoperitoneum following liver mass biopsy in the setting of post-ERCP pneumobilia
}

\author{
Fredy Nehme, Imad Nassif
}

Department of Internal Medicine, Kansas University School of Medicine - Wichita, Wichita, Kansas, USA

\section{Correspondence to} Fredy Nehme, nehme.fredy@ gmail.com

Accepted 23 June 2017
CrossMark

To cite: Nehme F, Nassif I. BMJ Case Rep Published Online First: [please include Day Month Year]. doi:10.1136/bcr-2017220997

\section{DESCRIPTION}

A 72-year-old woman presented with a 1-week history of fatigue, weight loss and painless jaundice. Liver chemistries confirmed cholestasis with hyperbilirubinaemia of $25.6 \mathrm{mg} / \mathrm{dL}$. An abdominal CT scan revealed multifocal liver lesions and dilation of intrahepatic and extrahepatic bile ducts. On endoscopic retrograde cholangiopancreatography (ERCP), a common bile duct stricture was found requiring dilation and insertion of a biliary stent. Cholangiogram demonstrated free bile drainage without contrast medium leakage. The patient then underwent CT-guided biopsy of a left lobe liver mass. On the next day, she complained of constant abdominal pain. She was afebrile and there were no peritoneal signs. Abdominal CT scan demonstrated localised free air in the peritoneal cavity (figure 1). The stent was at the proper position and pneumobilia of the common bile duct and intrahepatic bile ducts was noted. The occurrence of free air in the peritoneal cavity post-ERCP raised significant concerns for duodenal or ductal perforation. Review of the CT-guided biopsy scan revealed intrahepatic pneumobilia along the tract of the biopsy needle (figure 2) suggesting that air has passed into the peritoneal cavity through Glisson's capsule after rupture of intrahepatic bile ducts containing air. The patient was treated conservatively and progressive improvement was noted.

Pneumobilia is a known complication of ERCP. The occurrence of free air in the peritoneal cavity after ERCP is a rare event usually related to duodenal or ductal perforation. ${ }^{1}{ }^{2}$ Duodenal or ductal perforation secondary to ERCP was unlikely given the absence of contrast medium leakage, the

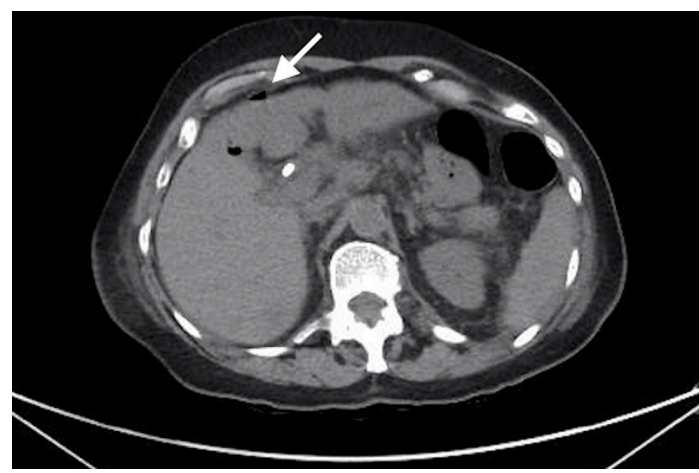

Figure 1 Abdominal CT scan showing localised free air in the peritoneal cavity anterior to the left hepatic lobe (arrow).

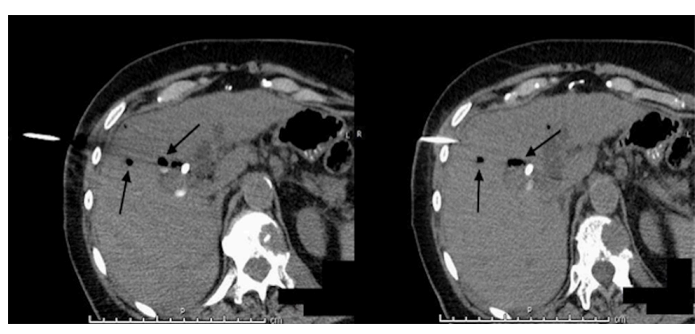

Figure 2 CT-guided biopsy scan revealing intrahepatic pneumobilia along the tract of the biopsy needle (arrow).

absence of retropneumoperitoneum and the localisation of pneumobilia along the tract of the biopsy needle. Therefore, pneumoperitoneum is likely due to the puncture of intrahepatic bile ducts containing air during the biopsy procedure, as air was introduced to the peritoneal cavity from pneumobilia along the tract of the biopsy needle. This case describes an unusual complication of liver biopsy following ERCP and emphasises on the importance of interpreting radiology findings in the right clinical setting.

\section{Learning points}

- The occurrence of free air in the peritoneal cavity after ERCP should raise concern of duodenal or ductal perforation.

- The absence of ductal contrast medium leakage on cholangiogram and the absence of retroperitoneum on $\mathrm{CT}$ scan make ductal or duodenal perforation unlikely in the setting of pneumoperitoneum.

- Radiology findings should always be interpreted in the right clinical setting.

Contributors FN: drafting of the manuscript and acquisition of data. IN: critical revision and supervision of the manuscript.

Competing interests None declared.

Patient consent Obtained.

Provenance and peer review Not commissioned; externally peer reviewed.

(c) BMJ Publishing Group Ltd (unless otherwise stated in the text of the article) . All rights reserved. No commercial use is permitted unless otherwise expressly granted.

\section{REFERENCES}

1 Chavalitdhamrong D, Donepudi S, Pu L, et al. Uncommon and rarely reported adverse events of endoscopic retrograde cholangiopancreatography. Dig Endosc 2014;26:15-22.

2 Pannu HK, Fishman EK. Complications of endoscopic retrograde cholangiopancreatography: spectrum of abnormalities demonstrated with CT. Radiographics 2001;21:1441-53. 
Copyright 2017 BMJ Publishing Group. All rights reserved. For permission to reuse any of this content visit http://group.bmj.com/group/rights-licensing/permissions.

BMJ Case Report Fellows may re-use this article for personal use and teaching without any further permission.

Become a Fellow of BMJ Case Reports today and you can:

- Submit as many cases as you like

- Enjoy fast sympathetic peer review and rapid publication of accepted articles

Access all the published articles

- Re-use any of the published material for personal use and teaching without further permission

For information on Institutional Fellowships contact consortiasales@bmjgroup.com

Visit casereports.bmj.com for more articles like this and to become a Fellow 